\title{
РОЛЬ ПРОЦЕСІВ ПЕРОКСИДНОГО ОКИСНЕННЯ ЛІПІДІВ І СИСТЕМИ АНТИОКСИДАНТНОГО ЗАХИСТУ В ПЕЧІНЦ У ПАТОГЕНЕЗІ ЕКСПЕРИМЕНТАЛЬНОЇ ПНЕВМОНІЇ ТА ІММОБІЛІЗАЦІЙНОГО СТРЕСУ І КОРЕКЦІЯ ЇХ ПОРУШЕНЬ КОРВІТИНОМ
}

Результати дослідження показали неспроможність системи антиоксидантного захисту утилізувати продукти пероксидного окиснення ліпідів при експериментальній пневмонії за умов стресу та ії виснаження в пізні періоди (6-та і 10-та доби) захворювання. При використанні корвітину, що має мембраностабілізувальну, імунокоригувальну, протизапальну дії, зменшилась пошкоджувальна дія продуктів пероксидного окиснення ліпідів і значно підвищився антиоксидантний захист. Це свідчить про коригувальний вплив корвітину на показники прооксидантної та антиоксидантної систем і дає можливість для подальшого вивчення і проведення експериментальних досліджень.

КЛЮЧОВІ СЛОВА: пероксидне окиснення ліпідів, система антиоксидантного захисту, експериментальна пневмонія, іммобілізаційний стрес, корвітин.

ВСТУП. Пневмонія займає провідне місце в структурі захворюваності органів дихання. Питання, яке стосується патогенезу, ранньої діагностики та терапії, набуло особливої гостроти і є одним з актуальних у сучасній пульмонології. Захворювання складає 30-40 \% від усіх захворювань легень, а у структурі загальної патології - лише 0,33 \%, та посідає четверте місце серед причин смертності. Летальність від пневмонії зросла від 1 до 9 \%, а за умови розвитку тяжких її ускладнень у реанімаційних відділеннях сягає 40-50 \%. Захворювання у XXI ст. залишається важливою медико-соціальною проблемою, тому що призводить до значних економічних збитків, спричиняє періоди непрацездатності. На сьогодні у практичній роботі лікаря часто зустрічається як гіпо-, так і гіпердіагностика пневмонії. Як відомо, несвоєчасна і хибна діагностика та неправильне лікування викликають розвиток тяжких ускладнень $[4,6,7]$.

Залишається не повністю з'ясованим патогенез розвитку пневмонії, не вивчено питання, які стосуються ролі прооксидантної (дієнові кон'югати, малоновий діальдегід) та антиоксидантної (супероксиддисмутаза, каталаза) систем у печінці в різні періоди розвитку пневмонії за умов іммобілізаційного стресу.

Що стосується корекції порушень вільнорадикального окиснення і стану антиоксидант๔ Н. М. Ференц, В. Р. Юревич, 2015. ного захисту за умов формування різних патологічних процесів в організмі, то перспективним є застосування біофлавоноїдів, серед яких особливе місце займає природний флавоноїд кверцетин, а саме його водорозчинна форма корвітин. Даний препарат має антиоксидантні, протизапальні, протинабрякові, антигістамінні та імуномоделюючі властивості [1].

Тому метою даного дослідження було з'ясувати роль процесів ліпопероксидації та антиоксидантної системи в патогенезі експериментальної пневмонії (ЕП) за умов іммобілізаційного стресу (IC) в експерименті й обґрунтувати доцільність застосування корвітину.

МЕТОДИ ДОСЛІДЖЕННЯ. Дослідження проводили на 48 морських свинках (самцях) масою 180-220 г, яких поділили на шість груп: 1-ша - контрольні (інтактні) тварини (8); 2-га тварини з ЕП та IC (8) на 1-шу добу до лікування; 3-тя - тварини з ЕП та IC (8) на 3-тю добу до лікування; 4-та - тварини з ЕП та IC (8) на 6-ту добу до лікування; 5-та - тварини з ЕП та IC (8) на 10-ту добу до лікування; 6-та - тварини 3 ЕП та IC на 10-ту добу після лікування корвітином, який вводили внутрішньом'язово у дозі 40 мг/кг маси впродовж 10 днів.

Експериментальну модель пневмонії відтворювали шляхом інтраназального зараження тварин культурою Staphylococcusaurus за 
методом В. Н. Шляпникова, Т. Л. Солодової, С. А. Степанова [8], іммобілізаційний стрес за методом П. Д. Горизонтова, О.І.Бєлоусова (1983) шляхом нетравматичної фіксації тварин на спині впродовж 3 год [3].

Потім декапітували інтактних тварин та морських свинок під ефірним наркозом на 1-шу, 3-тю, 6-ту і 10-ту доби розвитку ЕП та IC до та після лікування корвітином на 10-ту добу експерименту.

Вміст дієнових кон'югатів (ДК) визначали за методом В. Б. Гаврилова, М.І.Мишкорудної [2], малонового діальдегіду (МДА) - за методом $€$. Н. Коробейникова [5], активність супероксиддисмутази (СОД) - за методом R. Fried [9], каталази (КT) - за R. Holmes [10].

Опрацьовували цифрові дані методом варіаційної статистики з використанням критерію Стьюдента.

РЕЗУЛЬТАТИ Й ОБГОВОРЕННЯ. ПіД ЧаС експериментальних досліджень спостерігали зміну активності системи антиоксидантного захисту та пероксидного окиснення ліпідів (ПОЛ) у динаміці розвитку експериментальної пневмонії за умов іммобілізаційного стресу.

Вміст дієнових кон'югатів та малонового діальдегіду визначали для оцінки інтенсивності процесів ПОЛ. Дієнові кон'югати - первинні продукти ПОЛ. Серед показників ПОЛ одним із найважливіших $€$ малоновий діальдегід кінцевий продукт ліпопероксидації, і його частка складає 40 \% від усіх продуктів окиснення ліпідів.

За умови поєднання патологічних процесів - експериментальної пневмонії та іммобілізаційного стресу вже на 1-шу добу спостерігали значне зростання в печінці показників як ПОЛ, так і антиоксидантної системи: збіль- шення СОД на $111 \%(p<0,05)$ і КТ на $80 \%$ $(p<0,05)$, а також підвищення активності МДА на $50 \%(p<0,05)$ та ДК на 65,2\% $(p<0,05)$ порівняно з контролем, що свідчило про активацію процесів пероксидації та антиоксидантної системи в морських свинок (рис. 1). На 3-тю добу ЕП та IC надалі зберігалося накопичення продуктів ПОЛ - зростання ДК на 100 \% $(p<0,05)$ і МДА на $61,5 \%(p<0,05)$ та паралельно зростали показники СОД на $123 \%$ $(p<0,05)$ і каталази на $7 \%(p<0,05)$ відповідно до величин інтактних тварин, що вказувало на продовження стимуляції прооксидантних та антиоксидантних систем і на збереження рівноваги між ПОЛ та антиоксидантною системою. Пізніше, на 6-ту добу, відзначали виснаження антиоксидантної системи - зменшення СОД на $47 \%(p<0,05)$ і каталази на $61 \%$ $(p<0,05)$ та значне нагромадження продуктів пероксидного окиснення ліпідів у печінці зростання вмісту ДК на 95,6 \% $(p<0,05)$ і МДА на $77 \%(p<0,05)$ проти величин інтактних тварин, що свідчило про значну стимуляцію прооксидантної і пригнічення антиоксидантної систем. На 10-ту добу ЕП та IC до лікування встановлено подальше пригнічення антиоксидантного захисту - зниження СОД на $56 \%$ $(p<0,05)$ і КТ на $63 \%(p<0,05)$ та продовження накопичення продуктів ПОЛ - збільшення ДК на $104 \%(p<0,05)$ і МДА на $92 \%(p<0,05)$ порівняно з 1-ю групою тварин.

Після десятиденного лікування корвітином морських свинок з ЕП за умов IC спостерігали значне пригнічення ПОЛ - зменшення ДК на $34 \%(p<0,05)$ і МДА на $30 \%(p<0,05)$ та зростання показників антиоксидантної системи збільшення СОД на $96 \%(p<0,05)$ і КТ на $85 \%$ $(p<0,05)$ порівняно з групою інтактних тварин, яких не піддавали дії цього препарату (рис. 2).

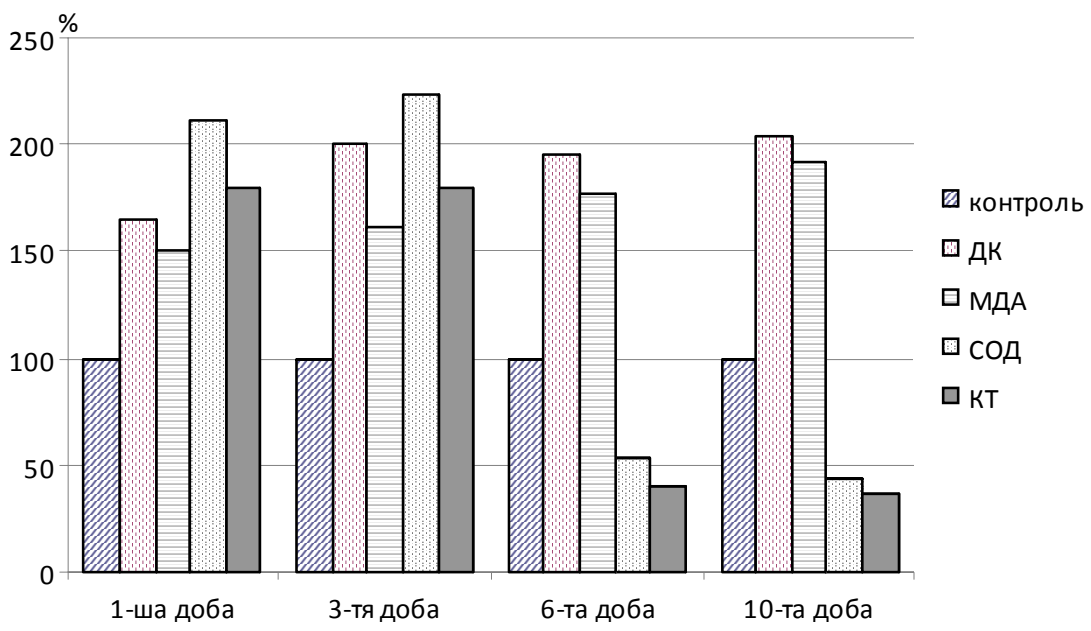

Рис. 1. Вміст продуктів пОЛ і стан антиоксидантної системи в печінці у динаміці розвитку ЕП за умов IC (\% від контролю). 


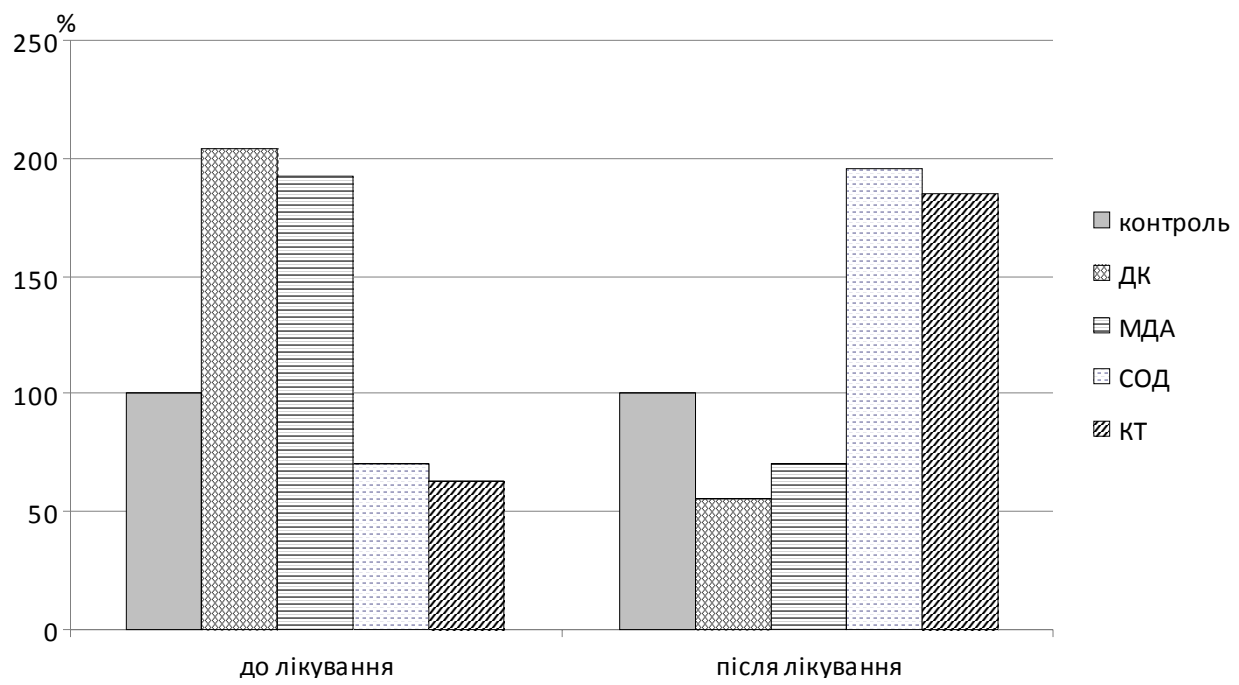

Рис. 2. Вплив корвітину на вміст ДК і МДА та активність СОД і КТ у печінці на 10-ту добу ЕП за умов IC (\% до та після лікування корвітином).

ВИСНОВКИ. Антиоксидантна система не спроможна утилізувати продукти ПОЛ при експериментальній пневмонії за умов стресу, відзначено їі виснаження в пізні періоди (6-та і 10-та доби) захворювання. При застосуванні корвітину, що має мембраностабілізувальну, імунокоригувальну, протизапальну дії, змен- шилась пошкоджувальна дія продуктів ПОЛ та значно підвищився антиоксидантний захист. Це свідчить про коригувальний вплив корвітину на показники прооксидантної та антиоксидантної систем і дає можливість для подальшого вивчення і проведення експериментальних досліджень.

\section{СПИСОК ЛІТЕРАТУРИ}

1. Биофлавоноиды как органопротекторы кверцетин, корвитин, квертин / под ред. А. А. Мобейко. - К. : Наукова думка, 2012. - 274 с.

2. Гаврилов В. Б. Спектрофотометрическое определение содержания гидроперекисей липидов в плазме крови / В. Б. Гаврилов, М. И. Мишкорудная // Лабораторная диагностика ишемической болезни сердца. - К. : Здоровье, 1989. - С. 170-171.

3. Горизонтов П. Д. Стресс и система крови / П. Д. Горизонтов, О. И. Белоусова, М. И. Федотов. М. : Медицина, 1983. - 338 с.

4. Казанцев В. А. Пневмония / В. А. Казанцев, Б. Б. Удальцов. - СПб. : Спец.Лит, 2003. - 118 с.

5. Коробейникова Э. Н. Модификация определения продуктов ПОЛ в реакции с тиобарбитуровой кислотой / Э. Н. Коробейникова // Лаб. дело. 1989. - № 7. - C. 8-10.
6. Регеда М. С. Пневмонія / М. С. Регеда. - 3-тє вид. - Львів : Сполом, 2005. - 138 с.

7. Регеда М. С. Пульмунологія : навч. посіб. / М. С. Регеда, І. Г. Гайдучок. - 2-ге вид. - Львів : Сполом, 2000. - 436 с.

8. Экспериментальные модели острых пневмоний, вызванных условно-патогенными бактериями, и их ассоциаций : метод. рек. / [В. Н. Шляпников, Т. Л. Солодова, С. А. Степанов и др.]. - Саратов : Саратовский медицинский институт, 1988. - 30 с.

9. Fried R. Enzymatik and non-enzymatic assay of superoxide ifilii / R. Fried // Biochemie. - 1975. 57, № 5. - P. 657-660.

10. Holmes R. epigenetic interconversions of the multiple forms of mouse liver catalase / R. Holms, C. Masters // FEBSLett. - 1970. - 11, № 1. P. 45-48. 
Н. М. Ференц, В. Р. Юревич

ЛЬВОВСКИЙ НАЦИОНАЛЬНЫЙ МЕДИЦИНСКИЙ УНИВЕРСИТЕТ ИМЕНИ ДАНИЛА ГАЛИЦКОГО

\section{РОЛЬ ПРОЦЕССОВ ПЕРОКСИДНОГО ОКИСЛЕНИЯ ЛИПИДОВ И СИСТЕМЫ АНТИОКСИДАНТНОЙ ЗАЩИТЫ В ПЕЧЕНИ В ПАТОГЕНЕЗЕ ЭКСПЕРИМЕНТАЛЬНОЙ ПНЕВМОНИИ И ИММОБИЛИЗАЦИОННОГО СТРЕССА И КОРРЕКЦИЯ ИХ НАРУШЕНИЙ КОРВИТИНОМ}

\section{Резюме}

Результаты исследования показали несостоятельность системы антиоксидантной защиты утилизировать продукты пероксидного окисления липидов при экспериментальной пневмонии в условиях стресса и ее истощение в поздние периоды (6-е и 10-е сутки) заболевания. При использовании корвитина, который обладает мембраностабилизирующим, иммунокорригирующим, противовоспалительным действиями, уменьшилось повреждающее действие продуктов пероксидного окисления липидов и значительно повысилась антиоксидантная защита. Это свидетельствует о корректирующем влиянии корвитина на показатели прооксидантной и антиоксидантной систем и дает возможность для дальнейшего изучения и проведения экспериментальных исследований.

КЛЮЧЕВЫЕ СЛОВА: пероксидное окисление липидов, система антиоксидантной защиты, экспериментальная пневмония, иммобилизационный стресс, корвитин.

\section{ROLE OF LIPID PEROXIDATION AND ANTIOXIDANT SYSTEM IN LIVER IN THE PATHOGENESIS OF EXPERIMENTAL PNEUMONIA AND IMMOBILIZATION STRESS AND CORRECTION OF THEIR VIOLATIONS BY CORVITIN}

\section{Summary}

The results showed the inability of the antioxidant system recycled products of lipid peroxidation in experimental pneumonia under stress and its depletion in the early periods of the disease. When using Corvitin that has membrane stabilizing, immunotherapy, anti-inflammatory action, decreased damaging effect of lipid peroxidation products and a significant increase in antioxidant protection. This demonstrates the impact of adjustment on indicators Corvitin prooxidant and antioxidant systems and provides an opportunity for further study and experimental research.

KEY WORDS: lipid peroxidation, antioxidant protection system, experimental pneumonia, immobilization stress, Corvitin.

Отримано 20.01.15

Адреса для листування: Н. М. Ференц, Львівський національний медичний університет імені Данила Галицького, вул. Пекарська, 69, Львів, 79010, Україна. 